\title{
Distribution of Lymphocyte Subsets in Bone Marrow and Peripheral Blood Is Associated with Haptoglobin Type Binding of Haptoglobin to the B-Cell Lectin $\mathrm{CD22}^{1}$ )
} \author{
Guido Van Nooten ${ }^{2}$ and Geert Leroux-Roels ${ }^{1}$ \\ 1 Central Laboratory, \\ 2 Department of Cardiac Surgery, \\ University Hospital Gent, Gent, Belgium
}

Michel Langlois ${ }^{1}$, Joris Delanghe ${ }^{1}$, Jan Philippé ${ }^{1}$, Jin Ouyang ${ }^{1}$, Dirk Bernard ${ }^{1}$, Marc De Buyzere ${ }^{1}$,

Summary: Haptoglobin is an acute phase protein showing a genetic polymorphism with 3 major types: Hp 1-1, Hp 2-1, and Hp 2-2. In this study, flow cytometric analysis demonstrated that all three haptoglobin types bind to CD22 on human B-lymphocytes with equal affinity. Comparison of reference values for lymphocyte subsets in peripheral blood and bone marrow showed significant differences between haptoglobin types. Haptoglobin 2-2 is associated with higher peripheral B-lymphocyte counts $(\mathrm{P}<0.001)$ and $\mathrm{CD} 4^{+} \mathrm{T}$-lymphocyte counts $(\mathrm{P}<0.05)$. In bone marrow, $\mathrm{CD} 4^{+} \mathrm{T}$-cell percentages were highest $(\mathrm{P}<0.001)$ but $\mathrm{B}$-cell percentages were lowest $(\mathrm{P}<0.001)$ in haptoglobin 2-2 type. A negative correlation between serum haptoglobin 1-1 concentration and peripheral B-cell counts was observed $(r=-0.663)$. Our results suggest that haptoglobin is involved in lymphocyte distribution. The present findings are a potential cause of over- or underestimation of lymphocyte subset counts in the clinical staging of immunodeficiency diseases.

\section{Introduction}

Haptoglobin is an acute phase sialoglycoprotein with haemoglobin-binding capacity (1). Haptoglobin is characterized by a molecular heterogeneity with three main genetic types: $\mathrm{Hp} \mathrm{1-1,} \mathrm{Hp} \mathrm{2-1,} \mathrm{and} \mathrm{Hp} \mathrm{2-2} \mathrm{(2).} \mathrm{This}$ polymorphism arises from variant $\alpha$-polypeptide chains $\left(\alpha_{1}\right.$ and $\left.\alpha_{2}\right)$, since the $\beta$-polypeptide chains of the three haptoglobin types are identical (3). The $\alpha$-chains are genetically determined by two autosomal alleles, $\mathrm{Hpl}$ and $H p 2(3,4)$. The homozygote Hp 1-1 is a small protein $\left(M_{\mathrm{r}}=86000\right)$ with the formula $\left(\alpha_{1} \beta\right)_{2}(5)$. The heterozygote Hp 2-1 with the formula $\left[\left(\alpha_{1} \beta\right)_{2}+\left(\alpha_{2} \beta\right)_{n}\right]$ $(\mathrm{n}=0,1,2, \ldots)$ is characterized by polymerization $\left(M_{\mathrm{r}}\right.$ $=165000)(5)$. In Hp 2-2 higher molecular mass forms are found $\left(M_{\mathrm{r}}=200000\right)$ with the formula $\left(\alpha_{2} \beta\right)_{\mathrm{n}}$ $(\mathrm{n}=3,4,5, \ldots)(5)$. Many functional differences between haptoglobin types have been described (6).

The protein plays an important role in the immunological and inflammatory response $(5,6)$. Haptoglobin inhibits prostaglandin synthesis, but this anti-inflammatory effect is less pronounced for Hp 2-2 (6-8). The Hp 2-2 type is over-represented among patients with autoimmune diseases $(9,10)$. Hp 2-2 individuals show a

\footnotetext{
1) This study was supported by a grant of the Nationaal Fonds voor Geneeskundig Wetenschappelijk Onderzoek (NFGWO) (No. 33003695).
}

stronger immune reactivity, as evidenced by higher antibody titres following vaccination $(11-13)$.

Interactions of haptoglobin with neutrophils and monocytes are well described (14-16), but haptoglobin binding to lymphocytes has never been investigated. Haptoglobin is known to inhibit various forms of lectin-induced lymphocyte transformations and there is some indication that haptoglobin modulates B-cell proliferation (17-19). More recently, it has been demonstrated that the carbohydrate moiety of human haptoglobin binds to the B-cell adhesion glycoprotein CD22 (20), suggesting that haptoglobin is involved in trafficking of lymphocytes. On the other hand, B- and T-lymphocyte counts are used as a diagnostic test in a number of diseases, particularly in the clinical staging of HIV-infection $(21,22)$.

In this study, we performed a flow cytometric analysis of haptoglobin binding to human lymphocytes. In order to study the physiological and clinical importance of this binding, we investigated the relationship between haptoglobin type and reference values for lymphocyte subsets in peripheral blood and in bone marrow.

\section{Materials and Methods}

Subjects

A population of 107 healthy Caucasian volunteers of Flemish descent was studied. Blood was obtained by venipuncture, allowed to clot, and centrifuged $(1000 \mathrm{~g}, 10$ minutes, room temperature). The 
supernatant serum was collected for analysis. Simultaneously drawn peripheral blood was collected in $\mathrm{K}_{2}$ EDTA-coated tubes for cytological study. In order to reduce biological variations, blood was drawn between 09:00 h and 10:00 h. All subjects gave informed consent to participate in this study. The study group consisted of 44 males (age: $40 \pm 11$ years) and 63 females (age: 42 \pm 11 years). Subjects under corticoid therapy or with recent infection, vaccination (within 12 months prior to sampling), and serum $\mathrm{C}$-reactive protein concentrations $>10 \mathrm{mg} / \mathrm{l}$ were excluded. There was no clinical evidence of any haematological or other disease. The haptoglobin type of the subjects was determined using starch gel electrophoresis of haemoglobin supplemented serum, followed by peroxidase staining (2).

\section{Bone marrow aspirates}

Human bone marrow samples were aspirated by sternal puncture from 45 haematologically normal patients undergoing cardiac surgery (33 males aged $64 \pm 7$ years and 12 females aged $58 \pm 8$ years). Informed consent was also obtained from these subjects. Bone marrow was collected in tubes containing $10 \mathrm{ml}$ RPMI 1642 medium (Gibco, Paisley, UK) and $50 \mu$ l sodium heparin $\left(5 \times 10^{6}\right.$ IU/1). The haptoglobin type was determined in serum collected from these patients before surgery. This study was approved by the ethical committee of the University Hospital of Gent.

\section{Immunophenotyping of peripheral blood lymphocytes}

Haematological examinations were always performed on fresh EDTA blood. Properties measured included the total counts of leukocytes and differential white blood cell count (Sysmex NE-8000, Toa Medical Electronics Co., Kobe, Japan) (23). Lymphocyte subsets were analysed by flow cytometry. For T-cell marker analysis, $5 \mu$ l of TriTEST ${ }^{\mathrm{TM}}$ reagent (Becton Dickinson, Mountain View, CA, USA) were applied to $50 \mu$ l EDTA-blood. This reagent is a combination of CD4-phycoerythrin, CD8-fluorescein isothiocyanate, and CD3-peridinin chlorophyll conjugated mouse monoclonal antibodies (isotypes: $\operatorname{IgG}_{1} \kappa$ ). B-lymphocytes were analyzed using phycoerythrin-labelled CD19-mouse antibodies (isotype: $\operatorname{IgG}_{1} \kappa$ ) (Coulter, Hialeah, FL, USA) $(5 \mu 1 / 50 \mu 1$ blood). Five microliters of CD56-phycoerythrin and CD3-fluorescein isothiocyanate mouse antibodies (isotypes: $\operatorname{IgG}_{1} \kappa$, both purchased from Coulter) were applied to $50 \mu \mathrm{l}$ blood for the determination of Natural Killer (NK, $\mathrm{CD}^{-} \mathrm{CD}^{-} 6^{+}$) cells. After incubation $\left(4^{\circ} \mathrm{C}, 30\right.$ minutes), erythrocytes were lysed by hypotonic shock and leukocytes were fixed using a Q-Prep Workstation (Coulter, Hialeah, FL, USA). The percentages of lymphocyte subsets in peripheral blood were determined on a FACSort flow cytometer, equipped with the Cellquest $^{\text {TM }}$ software (Becton Dickinson, Mountain View, CA, USA). The absolute numbers of lymphocyte subsets were calculated by multiplying the percentages of $\mathrm{CD}^{+}-, \mathrm{CD}^{+} \mathrm{CD}^{+}-$, $\mathrm{CD}^{+} \mathrm{CD}^{+}-, \mathrm{CD} 19^{+}$, and $\mathrm{CD}_{3}^{-} \mathrm{CD}^{+} 6^{+}$-cells by the total number of peripheral blood lymphocytes.

\section{Immunophenotyping of bone marrow lymphocytes}

Immediately after collection of heparinized bone marrow, mononuclear cells were separated by density gradient centrifugation on Lymphoprep ${ }^{\circledR}$ (Nycomed, Oslo, Norway), washed three times in Hank's balanced salt solution (Gibco, Paisley, UK), and resuspended in RPMI 1642 medium to a final cell count of $10^{9} / 1$. Lymphocyte subsets were evaluated using Simultest ${ }^{\mathrm{TM}}$ reagents LeucoGATE $^{\mathrm{TM}}$ (CD45/CD14), Control $\gamma_{1} / \gamma_{1}\left(\mathrm{IgG}_{1} / \mathrm{IgG}_{1}\right)$, CD3-fluorescein isothiocyanate/CD4-phycoerythrin, CD3-fluorescein isothiocyanate/CD8-phycoerythrin, CD3-fluorescein isothiocyanate/CD56 + CD16-phycoerythrin, and CD3-fluorescein isothiocyanate/ CD19-phycoerythrin (Becton Dickinson). Twenty microliters of Simultest ${ }^{\mathrm{TM}}$ reagents were applied to $100 \mu \mathrm{l}$ of cell suspensions. Phenotyping was performed on a FACSort flow cytometer, making use of the SimulSET ${ }^{\mathrm{TM}}$ software (Becton Dickinson, Mountain View, CA, USA).

\section{Determination of haptoglobin and C-reactive protein}

Concentrations of haptoglobin and C-reactive protein in serum were measured by fixed-time immunonephelometry on a BN II nephelometer (Behringwerke AG, Marburg, Germany) (24). Rabbit anti-human protein antisera, controls, and standards were obtained from Behringwerke. For each assay, we used one single batch of antiserum. Calibrations were done with the same standard batch. The serum protein concentrations were expressed according to IFCC-standards $(25,26)$.

\section{Direct haptoglobin binding to lymphocytes}

Purified human haptoglobin type 1-1, 2-1, and 2-2 preparations were a kind gift of Behringwerke AG (Marburg, Germany). The purity of the material was checked by SDS-PAGE. Haptoglobin types were conjugated with fluorescein isothiocyanate (Sigma Chemical Co., St. Louis, MO, USA), (0.05 mg fluorescein isothiocyanate per $\mathrm{mg}$ haptoglobin) in a $0.25 \mathrm{~mol} / \mathrm{l}$ carbonate buffer, 0.15 $\mathrm{mol} / \mathrm{l} \mathrm{NaCl}, \mathrm{pH} 9$ at $4{ }^{\circ} \mathrm{C}$ overnight. The solution was dialyzed in order to separate haptoglobin-fluorescein isothiocyanate from free fluorescein isothiocyanate.

For haptoglobin binding analysis, $100 \mu \mathrm{l}$ of peripheral blood mononuclear cell suspensions $\left(10^{9} / 1\right)$ were incubated $\left(4^{\circ} \mathrm{C}, 30 \mathrm{~min}\right)$ with $100 \mu \mathrm{l}$ of haptoglobin-fluorescein isothiocyanate $(1 \mathrm{~g} / \mathrm{l})$. Haptoglobin was always applied to cells obtained from subjects of the same haptoglobin type. In order to phenotype the haptoglobin binding cells, $5 \mu$ l of phycoerythrin-labelled mouse antibodies against CD4 $\left(\mathrm{IgG}_{1} \kappa\right.$, Coulter), CD8 ( $\operatorname{IgG}_{1} \kappa$, Coulter), CD3 ( $\operatorname{IgG}_{1} \kappa$, Becton Dickinson), CD19 ( $\operatorname{IgG}_{1} \kappa$, Coulter), or CD56 ( $\operatorname{IgG}_{1} \mathrm{~K}$, Coulter) were applied as well. After incubation $\left(4^{\circ} \mathrm{C}, 30 \mathrm{~min}\right)$, the cells were washed twice and resuspended to $0.5 \mathrm{ml}$ with phosphatebuffered saline. Flow cytometric analysis was then performed on a FACSort flow cytometer. Lymphocytes were gated using a forward scatter-side scatter plot.

\section{Indirect haptoglobin detection on lymphocytes}

Haptoglobin binding to lymphocytes was also investigated by indirect immunofluorescence. Therefore, $100 \mu \mathrm{l}$ of mononuclear cell suspensions $\left(10^{9} / 1\right)$ were incubated $\left(4^{\circ} \mathrm{C}, 30 \mathrm{~min}\right)$ with $1 \mathrm{ml}$ of purified haptoglobin $(1 \mathrm{~g} / \mathrm{l})$ and washed in phosphate-buffered saline. In a second step, $100 \mu$ l of cell suspensions were incubated $\left(4^{\circ} \mathrm{C}, 30 \mathrm{~min}\right)$ with $5 \mu \mathrm{l}$ of sheep antihuman haptoglobin antiserum (The Binding Site, Birmingham, UK), diluted $1: 10$ in phosphatebuffered saline, and were washed twice in phosphate-buffered saline. Five microliters of donkey anti-sheep IgG-fluorescein isothiocyanate (The Binding Site), diluted $1: 20$ in phosphate-buffered saline, and $5 \mu \mathrm{l}$ of phycoerythrin-labelled antibodies (CD4, CD8, $\mathrm{CD} 3, \mathrm{CD} 19, \mathrm{CD} 56)$ were then applied to the cells. In order to eliminate (false-positive) Fc binding of the first antibody, cells were preincubated $\left(4^{\circ} \mathrm{C}, 30 \mathrm{~min}\right)$ with normal sheep Ig (Sigma Chemical Co.). As a negative control for the second antibody, cells were incubated with donkey anti-sheep IgG-fluorescein isothiocyanate and with phycoerythrin-labelled mouse antibodies only.

Affinity of haptoglobin to the plasma membrane of lymphocytes was studied using a similar procedure but with decreasing concentrations of purified haptoglobin $(1 \mathrm{~g} / \mathrm{l})$, diluted $1: 2$ to $1: 1024$ in phosphate-buffered saline. The affinity constant $K$ was calculated using the equation

$$
K=\frac{\text { [occupied binding sites] }}{\text { [free binding sites] [Hp] }}
$$

where $[\mathrm{Hp}]$ represents the molar concentration of haptoglobin (27).

\section{Interference of haemoglobin and CD22 antibodies}

Human haemoglobin was purchased from Sigma Chemical Co. (St. Louis, MO, USA). In order to study the effect of haemoglobin on haptoglobin binding to lymphocytes, $10 \mu \mathrm{l}$ of the haemoglobin solution $(40 \mathrm{~g} / \mathrm{l})$ were applied 15 minutes after application of purified haptoglobin to $100 \mu \mathrm{l}$ of the mononuclear cell suspension $\left(30 \mathrm{~min}, 4^{\circ} \mathrm{C}\right)$. In order to study inhibition of haptoglobin binding by CD22 antibodies, the cells were preincubated for $30 \mathrm{~min}$ at $4^{\circ} \mathrm{C}$ with $10 \mu \mathrm{l}$ of mouse anti-human CD22 antibodies $(140 \mathrm{mg} / \mathrm{l})$ (Dako A/S, Glostrup, Denmark). In both experiments, haptoglobin binding to lymphocytes was detected as previously 
Tab. 1 Age, gender, peripheral blood leukocyte counts, lymphocyte subset counts, $\mathrm{CD}^{+} / \mathrm{CD}^{+} \mathrm{T}$ cell ratio, and serum haptoglobin and $\mathrm{C}$-reactive protein concentrations of the study population according to haptoglobin (Hp) type.

\begin{tabular}{|c|c|c|c|}
\hline & Hp 1-1 & Hp 2-1 & Hp 2-2 \\
\hline $\mathbf{n}$ & 21 & 51 & 35 \\
\hline Age (years) & $43 \pm 13^{a}$ & $41 \pm 9$ & $40 \pm 12$ \\
\hline Males/females & $9 / 12$ & $22 / 29$ & $13 / 22$ \\
\hline Leukocytes $\left(10^{9} / 1\right)$ & $6.31 \pm 1.72$ & $6.22 \pm 1.56$ & $6.62 \pm 1.96$ \\
\hline Neutrophils $\left(10^{9} / 1\right)$ & $4.05 \pm 1.31$ & $3.67 \pm 1.16$ & $3.99 \pm 1.64$ \\
\hline Eosinophils $\left(10^{9} / 1\right)$ & $0.15 \pm 0.08$ & $0.20 \pm 0.14$ & $0.19 \pm 0.15$ \\
\hline Basophils $\left(10^{9} / 1\right)$ & $0.03 \pm 0.02$ & $0.05 \pm 0.03$ & $0.04 \pm 0.03$ \\
\hline Monocytes $\left(10^{9} / 1\right)$ & $0.53 \pm 0.16$ & $0.56 \pm 0.19$ & $0.57 \pm 0.20$ \\
\hline Lymphocytes $\left(10^{9} / 1\right)$ & $1.54 \pm 0.47$ & $1.73 \pm 0.49$ & $1.83 \pm 0.47^{b}$ \\
\hline $\mathrm{CD} 19^{+}\left(10^{9} / 1\right)$ & $0.17 \pm 0.06$ & $0.21 \pm 0.06$ & $0.26 \pm 0.09^{c}$ \\
\hline $\mathrm{CD}^{+}\left(10^{9} / 1\right)$ & $1.03 \pm 0.29$ & $1.21 \pm 0.39$ & $1.24 \pm 0.38$ \\
\hline $\mathrm{CD}^{+} \mathrm{CD}^{+}\left(10^{9} / 1\right)$ & $0.63 \pm 0.13$ & $0.76 \pm 0.22$ & $0.79 \pm 0.28^{b}$ \\
\hline $\mathrm{CD}^{+} \mathrm{CD}^{+}\left(10^{9} / 1\right)$ & $0.39 \pm 0.17$ & $0.42 \pm 0.21$ & $0.43 \pm 0.16$ \\
\hline $\mathrm{CD}^{-} \mathrm{CD}^{-6^{+}}\left(10^{9} / 1\right)$ & $0.16 \pm 0.06$ & $0.20 \pm 0.11$ & $0.21 \pm 0.08$ \\
\hline $\mathrm{CD}^{+} / \mathrm{CD}^{+}{ }^{+}$ & $1.84 \pm 0.64$ & $2.00 \pm 0.73$ & $2.03 \pm 0.99$ \\
\hline Haptoglobin (g/l) & $1.31 \pm 0.53$ & $1.00 \pm 0.40$ & $0.77 \pm 0.43^{c}$ \\
\hline $\begin{array}{l}\text { C-reactive protein } \\
(\mathrm{mg} / \mathrm{l})\end{array}$ & $3.1 \pm 2.8$ & $2.9 \pm 3.5$ & $3.0 \pm 2.9$ \\
\hline
\end{tabular}

a All values: Mean $\pm \mathrm{SD}$.

b $P<0.05$ (ANOVA).

c $P<0.001$ (ANOVA).

described. The mean fluorescence and the number of positive cells obtained without haemoglobin or anti-CD22 incubation was equalized to $100 \%$ (control). Mean fluorescence and the number of positive cells after incubation with haemoglobin or anti-CD22 were expressed as percentage of control. The difference between both percentages was a measure for the degree of inhibition of haptoglobin binding.

\section{Statistics}

Values are expressed as means \pm SD. Validity of Hardy-Weinberg equilibrium was tested using the chi-square test. Comparisons of cell counts, cell percentages, and protein concentrations between haptoglobin type groups were carried out using ANOVA. Correlations between data were examined using regression analysis. Statistical significance was considered at the level $P<0.05$. Adjustment for multiple testing was done when appropriate using the Bonferroni correction.

\section{Results}

Haptoglobin gene frequency of the study population

In the study population, haptoglobin type frequencies were 0.196 (Hp 1-1), 0.477 (Hp 2-1), and 0.327 (Hp 22). Allele frequencies of $0.40(\mathrm{Hpl})$ and $0.60(\mathrm{Hp} 2)$ were obtained. These results are in agreement with Hardy-Weinberg's equilibrium and with earlier studies on Flemish subjects $(13,28)$. Age and gender of the subjects according to haptoglobin type are given in table 1 .

\section{Total and differential leukocyte counts}

In peripheral blood, no differences between haptoglobin types were found for total leukocyte counts (tab. 1). Differential counts of granulocytes and monocytes were comparable but total lymphocyte count was significantly higher in haptoglobin $2-2$ subjects $(P<0.05)$.

\section{Peripheral blood lymphocyte subsets}

The flow cytometric phenotype data presented in table 1 correspond to normal reference values for peripheral blood lymphocyte subsets in Caucasians (29). No significant differences were found in percentages of $\mathrm{CD}^{+}{ }_{-}, \mathrm{CD}_{3}{ }^{+} \mathrm{CD}^{+}{ }^{-}, \mathrm{CD}^{+} \mathrm{CD}^{+}-, \mathrm{CD} 19+-$, and $\mathrm{CD}^{-}{ }^{-} \mathrm{CD} 56^{+}$-cells between haptoglobin types. Absolute peripheral $\mathrm{CD}^{+}, \mathrm{CD}^{+}{ }^{+} \mathrm{CD} 8^{+}$, and $\mathrm{CD}^{-}{ }^{-} \mathrm{CD} 56^{+}$ counts $\left(10^{9} / 1\right)$ were comparable as well. However, $\mathrm{CD}^{+} \mathrm{CD}^{+}$-cell counts were significantly higher in Hp 2-2 subjects $(P<0.05)$. The $\mathrm{CD}^{+} / \mathrm{CD8}^{+}$T-cell ratio was comparable in the three groups. Furthermore, peripheral $\mathrm{CD} 19^{+}$-cell counts showed marked differences according to the haptoglobin type $(P<0.001)$. In the $\mathrm{Hp} \mathrm{1-1}$ group, peripheral $\mathrm{CD}^{+} 9^{+}$counts are low. Hp 2-2 is associated with the highest $\mathrm{CD} 19^{+}$ counts. Neither age nor gender of the subjects were related to peripheral $\mathrm{CD} 9^{+}-$and $\mathrm{CD}^{+} \mathrm{CD}^{+}$-cell counts.

\section{Serum haptoglobin and C-reactive protein concentrations}

The concentrations of haptoglobin measured in serum correspond to earlier studies (tab. 1) $(6,13)$. In the overall population, peripheral $\mathrm{CD} 19^{+}$-cell counts were not related to serum haptoglobin levels. However, in the Hp 1-1 group, a negative correlation of $\mathrm{CD} 19^{+}$ count with serum haptoglobin concentration was obtained: $y$ (peripheral CD19 ${ }^{+}$-cells, $10^{9} / 1$ ) $=-67.73 x$ (serum Hp 1-1 concentration, g/l) + 262.91; $r=-0.663, S_{y x}=44.83(P<0.01)$ (fig. 1). Such correlations were not observed in $\mathrm{Hp} \mathrm{2-1} \mathrm{and} \mathrm{Hp}$ 2-2 subjects. Similarly, peripheral $\mathrm{CD}^{+} \mathrm{CD}^{+}$counts were not related to serum haptoglobin levels. Serum Creactive protein concentrations were comparable between all haptoglobin types (tab. 1).

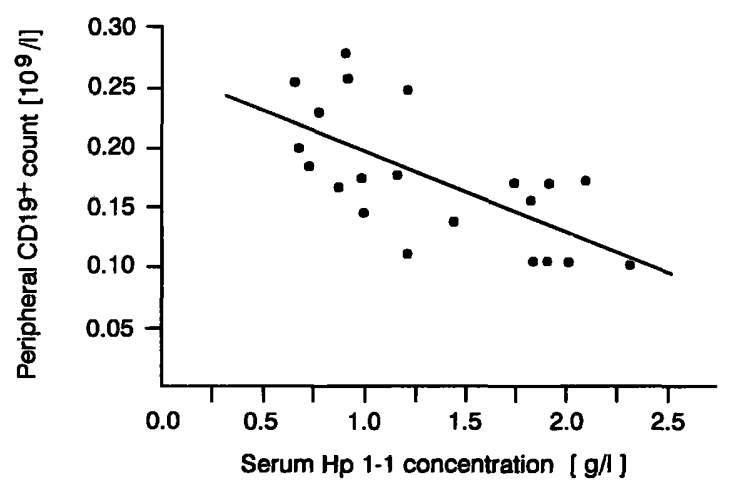

Fig. 1 Relation between peripheral B cell count $\left(10^{9} / 1\right)(y)$ and serum haptoglobin $(\mathrm{Hp})$ concentration $(\mathrm{g} / \mathrm{l})(x)$ in Hp 1-1 subjects: $y=-67.73 x+262.91, r=-0.663, P<0.01, \mathrm{n}=21$. 
Tab. 2 Lymphocyte subset percentages and $\mathrm{CD} 4^{+} / \mathrm{CD} 8^{+} \mathrm{T}$ cell ratio in human bone marrow according to haptoglobin $(\mathrm{Hp})$ type.

\begin{tabular}{lccl}
\hline & Hp 1-1 & Hp 2-1 & Hp 2-2 \\
\hline $\mathrm{n}$ & 8 & 26 & 11 \\
$\mathrm{CD} 9^{+}(\%)$ & $38.4 \pm 11.0^{\mathrm{a}}$ & $27.9 \pm 6.4$ & $18.4 \pm 7.97^{\mathrm{b}}$ \\
$\mathrm{CD}^{+}(\%)$ & $49.8 \pm 16.5^{\mathrm{c}}$ & $63.5 \pm 5.2$ & $68.8 \pm 9.4$ \\
$\mathrm{CD}^{+}{ }^{+} \mathrm{CD} 4^{+}(\%)$ & $21.8 \pm 9.1^{\mathrm{b}}$ & $39.0 \pm 6.5$ & $44.5 \pm 10.8$ \\
$\mathrm{CD}^{+} \mathrm{CD}^{+}(\%)$ & $24.9 \pm 14.2$ & $24.4 \pm 5.9$ & $24.7 \pm 10.8$ \\
$\mathrm{CD}^{-} \mathrm{CD56}^{+}(\%)$ & $9.6 \pm 5.4$ & $8.5 \pm 2.8$ & $14.5 \pm 5.6$ \\
$\mathrm{CD}^{+} / \mathrm{CD}^{+}$ & $1.21 \pm 0.99$ & $1.75 \pm 0.72$ & $2.23 \pm 1.35$ \\
\hline
\end{tabular}

a All values: Mean $\pm \mathrm{SD}$.

b $P<0.001$ (ANOVA).

c $P<0.05$ (ANOVA).

\section{Bone marrow lymphocyte subsets}

In human bone marrow aspirates, percentages of $\mathrm{CD}^{+}{ }^{-}, \mathrm{CD}^{+} \mathrm{CD}^{+}{ }^{+}, \mathrm{CD}^{+} \mathrm{CD}^{+}{ }^{-}, \mathrm{CD}_{1} 9^{+}$, , and $\mathrm{CD}^{-}{ }^{-} \mathrm{CD} 56^{+}$-cells were compared between haptoglobin types. As shown in table 2, total $\mathrm{CD}^{+}$bone marrow cell percentages were lowest in Hp 1-1 type $(P<0.05)$, which was exclusively caused by lower $\mathrm{CD}^{+} \mathrm{CD}^{+}$percentages $(P<0.001)$. Significant differences for $\mathrm{CD}^{+}{ }^{+} \mathrm{CD} 8^{+}$and $\mathrm{CD} 3{ }^{-} \mathrm{CD} 56^{+}$bone marrow cells were not observed. A nearly significant haptoglobin type-dependence of $\mathrm{CD} 4^{+} / \mathrm{CD} 8^{+} \mathrm{T}$-cell ratio was obtained in bone marrow $(P=0.079)$. In contrast to peripheral blood, $\mathrm{Hp} 2-2$ is associated with the lowest $\mathrm{CD}_{19}{ }^{+}$bone marrow cell percentages $(P<0.001)$.

Relations between bone marrow and peripheral blood lymphocytes

Peripheral blood lymphocyte subset counts were determined in EDTA-blood obtained from 10 patients before cardiac surgery and compared with the data obtained in their bone marrow aspirates. Bone marrow $\mathrm{CD} 3{ }^{+} \mathrm{CD} 4{ }^{+}$ percentages $(y)$ correlated positively with peripheral $\mathrm{CD}^{+} \mathrm{CD}^{+}$counts $\left(x, 10^{9} / 1\right): y=0.03 x+11.38$, $r=0.742, S_{y x}=7.53(P<0.05)$. In contrast, a negative correlation was found between $\mathrm{CD} 19^{+}$bone marrow percentages $(y)$ and peripheral $\mathrm{CD} 19^{+}$counts $\left(x, 10^{9} / 1\right)$ : $y=-0.21 x+66.36, \quad r=-0.779, \quad S_{y x}=6.75$ $(P<0.01)$.

Relation between serum haptoglobin concentrations and bone marrow lymphocyte percentages

In the overall group, no correlations were obtained between serum haptoglobin concentrations and lymphocyte subset percentages in bone marrow. However, in Hp 1-1 subjects, $\mathrm{CD} 19^{+}$percentages correlated positively with serum haptoglobin concentrations: $y\left(\% \mathrm{CD} 19^{+}\right.$bone marrow cells) $=34.30 x$ (serum Hp 1-1 concentration, $\mathrm{g} / \mathrm{l}$ ) $-7.50, r=0.770, S_{y x}=7.58(P<0.05)$. This is in contrast with the negative correlation of $\mathrm{Hp} 1-1$ concentration with peripheral $\mathrm{CD} 19^{+}$count. In all haptoglobin types, $\mathrm{CD}^{+}{ }^{+} \mathrm{CD} 4^{+}$bone marrow percentages were not related to serum haptoglobin concentrations.

\section{Binding of haptoglobin-fluorescein \\ isothiocyanate to lymphocytes}

Figure 2 is a typical flow cytometric dot plot showing haptoglobin-fluorescein isothiocyanate binding to the cell-surface of $\mathrm{CD} 19^{+}$-lymphocytes. Such $\mathrm{Hp}^{+} \mathrm{CD} 19^{+}-$ cell populations were obtained with Hp 1-1 $(n=5)$, Hp 2-1 $(n=5)$, and Hp 2-2 $(n=5)$. No haptoglobin-fluorescein isothiocyanate binding was detected on $\mathrm{CD} 4^{+}$, $\mathrm{CD}^{+}-\mathrm{CD}^{+}{ }_{-}$, and $\mathrm{CD}_{6} 6^{+}$-cells. As demonstrated in previous studies, haptoglobin binding was also observed in the monocyte and granulocyte populations (14-16).

\section{Indirect haptoglobin detection on lymphocytes}

Identical results were obtained after indirect haptoglobin staining using sheep anti-haptoglobin antiserum and donkey anti-sheep IgG-fluorescein isothiocyanate. In all haptoglobin types, the flow cytometric dot plots of $\mathrm{Hp}^{+} \mathrm{CD} 19^{+}$-lymphocytes were comparable with the direct haptoglobin staining (fig. 3). Control experiments were performed in order to exclude Fc binding of the two antibodies. $\mathrm{Hp}^{+} \mathrm{CD} 19^{+}$-lymphocytes were also obtained after preincubation of the cells with normal sheep immunoglobulin. On the other hand, no $\mathrm{Hp}^{+} \mathrm{CD} 19^{+}$ double-positive staining was observed after incubation of the cells with donkey anti-sheep IgG-fluorescein isothiocyanate and phycoerythrin-labelled CD19 antibodies only.

\section{Effect of haemoglobin and CD22-antibodies on haptoglobin binding}

Flow cytometric analysis showed that the addition of haemoglobin to the cell suspensions did not cause a sig-

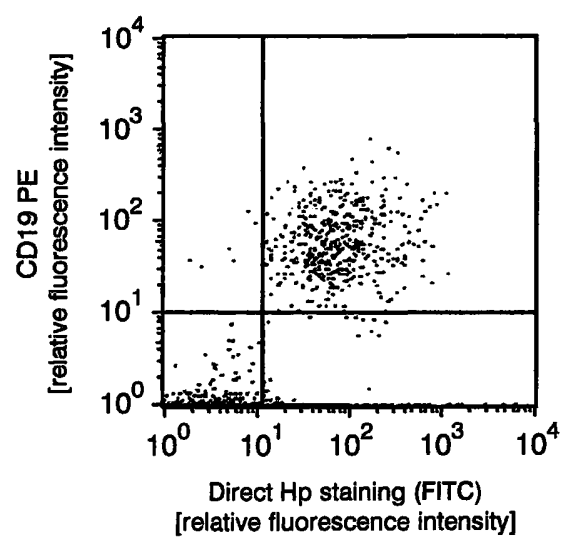

Fig. 2 Illustration of haptoglobin (Hp) binding to B cells. Shown is a flow cytometric dot plot of log fluorescein isothiocyanate (FITC) fluorescence (Hp) vs log phycoerythrin (PE) fluorescence (CD19) of lymphocytes. The plot was obtained after incubation of peripheral blood mononuclear cells with human Hp-FITC and mouse anti-CD19 PE. 
nificant reduction of Hp 1-1 $(n=3)$, Hp 2-1 $(n=3)$, or Hp 2-2 $(\mathbf{n}=3)$ binding to $\mathrm{CD} 19^{+}$-lymphocytes. In contrast, binding of haptoglobin to $\mathrm{CD} 19^{+}$-lymphocytes could be inhibited by preincubation of the cells with CD22 antibodies. The CD22 antibodies reduced the mean fluorescein isothiocyanate fluorescence by 78 $\pm 5 \%$ and the number of positive cells by $96 \pm 2 \%$ $(n=9)$. Comparable results were obtained for all three haptoglobin types.

\section{Affinity of haptoglobin towards CD22}

The affinity constants $K$ observed for Hp-CD22 binding

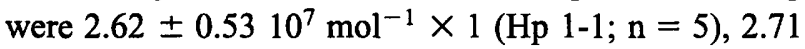

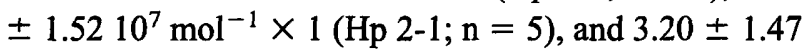
$10^{7} \mathrm{~mol}^{-1} \times 1($ Hp $2-2 ; \mathrm{n}=5)$. Figure 4 shows the bound/free ratios (occupied CD22 binding sites/free CD22 binding sites) at increasing molar concentrations of haptoglobin. Approximately $10^{4} \mathrm{CD} 22$ molecules are

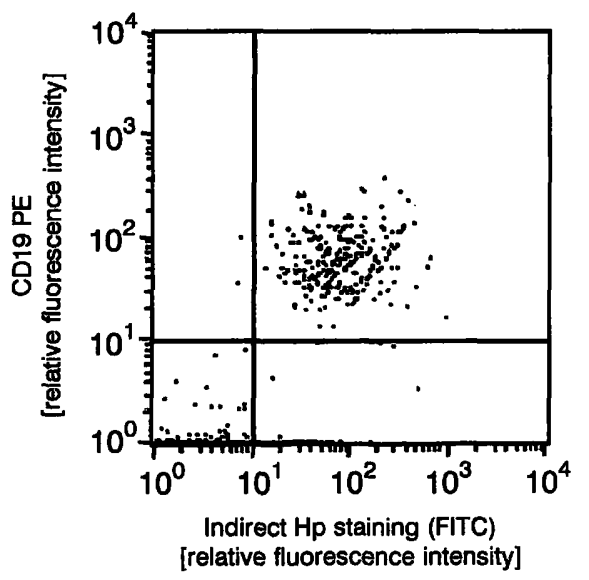

Fig. 3 Indirect detection of haptoglobin (Hp) binding to B cells. The flow cytometric dot plot showing log fluorescein isothiocyanate (FITC) fluorescence (Hp) vs log phycoerythrin (PE) fluorescence (CD19) was obtained after incubation of lymphocytes with human $\mathrm{Hp}$, sheep anti-Hp, donkey anti-sheep FITC, and mouse anti-CD19 PE.

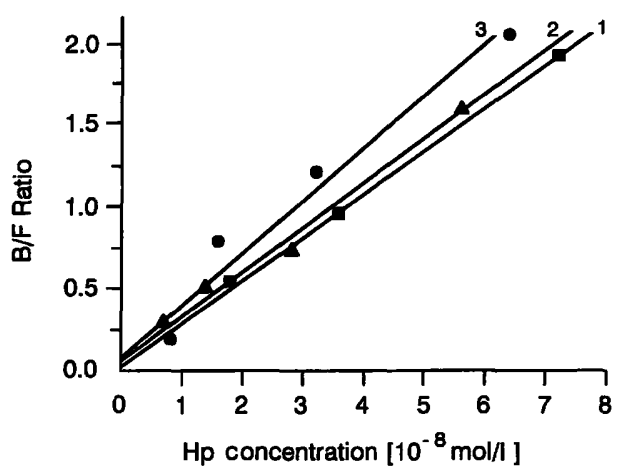

Fig. 4 Binding of Hp types 1-1, 2-1, and 2-2 to B lymphocytes. Shown are the $\mathrm{B} / \mathrm{F}$ ratios (bound/free) of $\mathrm{CD} 22$ binding sites at increasing molar $\mathrm{Hp}$ concentrations. The percentages of $\mathrm{Hp}$-binding $\mathrm{CD} 19^{+}$lymphocytes were multiplied by the mean FITC fluorescence of the positive $\mathrm{CD} 19^{+}$cell populations. The $\mathrm{B} / \mathrm{F}$ ratios were calculated from the maximum $\mathrm{Hp}-\mathrm{CD} 22$ saturation: $\mathrm{B} / \mathrm{F}=$ [observed binding]/[maximal binding - observed binding].

1 - $\mathrm{Hp} \mathrm{1-1,} 2 \backsim \mathrm{Hp} \mathrm{2-1,3} 3 \bullet \mathrm{Hp} \mathrm{2-2}$ present on B-lymphocytes (30). Taking into account the calculated mean B-cell counts (tab. 1), this corresponds to CD22 molecule number concentrations of approxi-

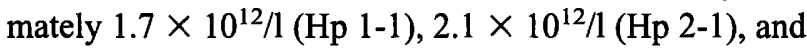
$2.6 \times 10^{12} / 1(\mathrm{Hp} \mathrm{2-2})$ in peripheral blood. From the mean molar concentrations of haptoglobin types 1-1 (14 $\left.\times 10^{-6} \mathrm{~mol} / \mathrm{l}\right), 2-1\left(6 \times 10^{-6} \mathrm{~mol} / \mathrm{l}\right)$, and $2-2(2.85$ $\left.\times 10^{-6} \mathrm{~mol} / \mathrm{l}\right)$, we can estimate that a negligible fraction $(<0.0001 \%)$ of plasma haptoglobin is present on Blymphocytes. However, the occupation of CD22 molecules by haptoglobin is type-dependent: the percentages of free CD22 molecules are approximately $0.25 \%$ (Hp $1-1), 0.70 \%$ (Hp 2-1), and $1.20 \%$ (Hp 2-2).

\section{Discussion}

Flow cytometric analysis demonstrated that haptoglobin binds to human B-lymphocytes in Hp 1-1, Hp 2-1, and Hp 2-2 individuals. In contrast, no significant binding was detected for T-cells and NK-cells.

The values for the affinity constant observed for haptoglobin binding $\left(2.80 \pm 0.5310^{7} \mathrm{~mol}^{-1} \times 1\right)$ are in agreement with those found by Hanasaki et al. who demonstrated that the carbohydrate moiety of the haptoglobin $\beta$-chain binds to human recombinant CD22 (20). The affinity constants were comparable for the three haptoglobin types. This is not surprising, since the haptoglobin $\beta$-chain is identical in all haptoglobin types. However, the number of free CD22 binding sites were estimated to be higher in Hp 2-2 blood.

Antibodies to CD22 block haptoglobin binding to Bcells, indicating that $\mathrm{CD} 22$ is indeed the binding site for haptoglobin. In contrast, addition of haemoglobin had no effect on haptoglobin binding to B-cells. Although the binding of haemoglobin to the $\beta$-chain of haptoglobin is characterised by a very high affinity $\left(>10^{10}\right.$ $\left.\mathrm{mol}^{-1} \times 1\right)(31)$, it does not interfere with the haptoglobin-CD22 binding. This suggests that the haptoglobin $\beta$ binding region for $\mathrm{CD} 22$ is different from the haemoglobin-binding site.

Reference values for peripheral blood lymphocytes differ significantly depending on the haptoglobin type. Total peripheral blood lymphocyte counts are highest in Hp 2-2 individuals, which is exclusively caused by higher B-cell and helper T-cell counts. This effect was even more pronounced in bone marrow helper T-cell percentages. In contrast, the lowest B-cell percentages were observed in bone marrow aspirates from $\mathrm{Hp} \mathrm{2-2}$ subjects. Haptoglobin type dependence was not observed for cytotoxic/suppressor T-cells and NK-cells in both peripheral blood and bone marrow.

The association of Hp 2-2 type with a higher number of peripheral circulating B-lymphocytes and helper Tlymphocytes partly explains the strong immunological 
reactivity in Hp 2-2 individuals $(5,6)$. The present findings can improve the interpretation of lymphocyte subset analysis in the practice of laboratory medicine, since Band T-cell counts are used as a diagnostic test in a number of diseases, such as primary or acquired immunodeficiencies and sarcoidosis (21).

Particularly, the knowledge of the patients' haptoglobin type is of interest for the interpretation of $\mathrm{CD}^{+} \mathrm{T}$-cell counts in the clinical staging of HIV-infected patients (22). Clinicians using the fixed classification criteria of HIV-disease may overestimate $\mathrm{CD}^{+}{ }^{+}$T-cell counts in Hp 2-2 patients (22). Therefore, absolute $\mathrm{CD}^{+}{ }^{+} \mathrm{T}$-cell counts should be interpreted with caution.

Measurements of serum haptoglobin concentration correspond to earlier studies and showed lowest haptoglobin levels in Hp 2-2 individuals $(6,13)$. The distribution volume of haptoglobin is about 1.5 times the plasma volume, so the measured serum concentration is in equilibrium with the concentration in bone marrow (4). The association of the haptoglobin type with reference values for B-cells and CD4 ${ }^{+} \mathrm{T}$-cells cannot be explained by an effect of haptoglobin concentration. However, serum Hp 1-1 concentration showed a negative correlation with peripheral B-lymphocyte count. In bone marrow, serum Hp 1-1 concentration correlated positively with B-cell percentage. These findings suggest a negative effect of Hp 1-1 on the number of peripheral circulating B-lymphocytes. Such correlations were not observed in the Hp 2-1 and Hp 2-2 groups.

Peripheral helper T-lymphocyte counts correlated positively with bone marrow helper T-cell percentages. However, for the B-cell markers, an inverse relation was observed between peripheral counts and bone marrow percentages. These observations support the view of Hanasaki et al. who postulated a role for haptoglobin in homing and trafficking of B-lymphocytes (20).

A lectin-like binding of haptoglobin to lymphocytes has been suggested by several authors $(5,6)$. Using a flow cytometric approach, we confirmed here the recent finding that haptoglobin binds to CD22 (20). CD22 is a cell-surface phosphoglycoprotein found on the majority of B-lymphocytes (32). The glycoprotein is a member of the immunoglobulin superfamily and is involved in antigen-induced B-cell activation and signal transduction $(32,33)$. CD22 is also an adhesion receptor and mediates interactions of B-cells with erythrocytes, T-lymphocytes, monocytes, neutrophils, and endothelial cells by specific binding to glycoproteins containing $\mathrm{N}$-linked oligosaccharides with terminal $\alpha 2-6$-linked sialic acid residues $(34,35)$. Addition- ally, CD22 has a function in T-cell activation via binding to CD45RO, a T-cell surface glycoprotein which modulates the signal transduced by the T-cell receptor (CD3/TCR complex) $(36,37)$.

The haptoglobin $\beta$-chain contains terminal $\alpha 2-6$ linked sialic acid residues (38), and is capable to inhibit the CD22 binding to TNF- $\alpha$-activated human umbilical vein endothelial cells (20). Our data demonstrate an important biological effect of haptoglobin on B-lymphocyte distribution as well, and further support earlier indications that haptoglobin modulates lymphocyte proliferation (28). Antibody production, however, is not influenced by the haptoglobin type: reference values for serum immunoglobulins are not type-dependent, except for IgA (39).

Many questions remain to be answered. These include: how can the haptoglobin type-dependence of B-cell reference values be explained? Hp 1-1, Hp 2-1, and Hp 22 differ in $\alpha$-polypeptide chain composition and in the presence of high molecular mass forms (4). Therefore, it is possible that the biological effect of $\mathrm{Hp}-\mathrm{CD} 22$ binding depends upon the presence or absence of multiple $\alpha_{1}$ - or $\alpha_{2}$-polypeptide chains in a specific orientation or conformation. Furthermore, the molar concentrations of $\mathrm{Hp} 2$ 2 in serum are low due to the presence of higher polymers, and the number of CD22 molecules occupied by haptoglobin is lowest in Hp 2-2.

It also remains to be explained why reference values for $\mathrm{CD}^{+} \mathrm{T}$-cells are influenced by the haptoglobin type. Since CD22-CD45 binding regulates TCR-mediated signal transduction $(36,37)$, haptoglobin may also participate in T-B-cell interaction. This could result in a negative or positive regulation of T-cell proliferation (36, 37).

\section{Conclusion}

We have demonstrated that Hp 1-1, Hp 2-1, and Hp 2-2 bind to CD22 on the cell-surface of human B-lymphocytes. Haptoglobin type is associated with the numbers of B-lymphocytes and helper T-lymphocytes present in peripheral blood and in bone marrow. This view provides new insights in the immunoregulatory mechanism of haptoglobin and improves the interpretation of lymphocyte subset analysis, particularly in the clinical staging of HIV-infection.

\section{Acknowledgements}

The authors wish to thank Mrs. L. Claeys and I. Verhelle for their skillful assistance. We are grateful to Prof. Dr. S. Baudner $\dagger$ (Behringwerke AG, Marburg, Germany) for kindly providing the purified haptoglobin preparations. 


\section{References}

1. Bowman BH. Haptoglobin. In: Bowman BH, editor. Hepatic plasma proteins. San Diego: Academic Press, 1993:159-67.

2. Smithies $\mathrm{O}$. Zone electrophoresis in starch gels: group variations in the serum proteins of normal human adults. Biochem $\mathrm{J}$ 1955; 61:629-41.

3. Bowman BH, Yang F. DNA sequencing and chromosomal locations of human plasma protein genes. In: Putnam FW, editor. The plasma proteins. Structure, function and genetic control. 2nd ed. London: Academic Press, 1987:12-48.

4. Schultze HE, Heremans JF, editors. Molecular biology of human proteins. Volume 1: Nature and metabolism of extracellular proteins. Amsterdam: Elsevier, 1966.

5. Lange V. Der Haptoglobin Polymorphismus - nicht nur eine genetische Markierungshilfe. Anthrop Anzeiger 1992; 50:281-302.

6. Langlois $\mathrm{M}$, Delanghe J. Biological and clinical significance of haptoglobin polymorphism in humans. Clin Chem 1996; 42:1589-600.

7. Kendall PA, Saeed SA, Collier HOJ. Identification of an endogenous inhibitor of prostaglandin synthetase with haptoglobin and albumin. Biochem Soc Transact 1979; 7:543-5.

8. Jue D-M, Shim B-S, Kang Y-S. Inhibition of prostaglandin synthase activity of sheep seminal vesicular gland by human serum haptoglobin. Molec Cell Biochem 1983; 51:141-7.

9. Rantapää Dahlqvist S, Frohlander N. Haptoglobin groups and rheumatoid arthritis. Hum Hered 1985; 35:207-11.

10. Rantapää Dahlqvist S, Beckman G, Beckman L. Serum protein markers in systemic lupus erythematosus. Hum Hered 1988; 38:44-7.

11. Nevo S, Sutton H. Association between response to typhoid vaccination and known genetic markers. Am J Hum Genet 1979; 20:461-9.

12. Friedel E, Schmidt M, Apstoloff E, Geserick G, Montag T, Kuhlmay J, Bode F. Ein wahrscheinlicher Zusammenhang zwischen Haptoglobintyp und immunogener Reaktivität nach Tetanusimmunierung. Dt Gesundh-wesen 1979; 34:376-7.

13. Louagie H, Delanghe J, De Sombere I, De Buyzere M, Hauser P, Leroux-Roels G. Haptoglobin polymorphism and immune response after hepatitis B vaccination. Vaccine 1993; 11:1188-90.

14. Oh SK, Pavlotski N, Tauber AI. Specific binding of haptoglobin to human neutrophils and its functional consequences. $J$ Leukoc Biol 1990; 47:142-8.

15. Wagner L, Gessl A, Baumgartner Parzer S, Base W, Waldhäusl W, Pasternack MS. Haptoglobin phenotyping by newly developed monoclonal antibodies. Demonstration of haptoglobin uptake into peripheral blood neutrophils and monocytes. J Immunol 1996; 156:1989-96.

16. El Ghmati SM, Van Hoeyveld EM, Van Strijp JAG, Ceuppens $\pi$, Stevens EAM. Identification of haptoglobin as an alternative ligand for CDI1b/CD18. J Immunol 1996; 156:2542-52.

17. Baskies AM, Chretien PB, Weiss JF, Makuch RW, Beveridge RA, Catalona WJ, et al. Serum glycoproteins in cancer patients: first reports of correlations with in vitro and in vivo parameters of cellular immunity. Cancer 1980; 45:3050-60.

18. Kudo J, Okubo H, Ikuta T, Hirata Y, Ishibashi H. Interaction of acute phase reactive (APR) proteins with lectins: its relationship to lymphocyte transformation. Biomed Res 1982; 3:417-21.

19. Basler MW, Burrel R. Purification of haptoglobin and its effects on lymphocytes and alveolar lymphocyte responses. Inflammation $1983 ; 7: 387-400$

20. Hanasaki K, Powell LD, Varki A. Binding of human plasma sialoglycoproteins by the B cell specific lectin CD22. Selective recognition of immunoglobulin $\mathrm{M}$ and haptoglobin. J Biol Chem 1995; 270:7543-50.

21. Friedman RB, Young DS, editors. Effects of disease on clinical laboratory tests. 2nd ed. Washington: AACC Press, 1989.

22. Saag MS. Natural history of HIV-1 disease. In: Broder S, Merigan TC, Bolognesi D, editors. Textbook of AIDS medicine. Baltimore: Williams \& Wilkins, 1994:45-53.
23. Devreese K, De Logi E, Francart C, Heyndrickx B, Philippé J, Leroux-Roels G. Evaluation of the automated haematology analyser Sysmex NE-8000. Eur J Clin Chem Clin Biochem 1991; 29:339-45.

24. Fink PC, Roemer M, Haeckel R, Fateh-Moghadam A, Delanghe J, Gressner AM, et al. Measurement of proteins with the Behring Nephelometer: a multicentre evaluation. J Clin Chem Clin Biochem 1989; 27:261-76.

25. Whicher JT, Ritchie RF, Johnson AM, Baudner S, Bienvenu J, Blirup-Jensen $S$, et al. A new international reference preparation for proteins in human serum (RPPHS 5). Clin Chem 1994; 40:934-8.

26. Dati F, Schumann G, Thomas L, Aguzzi F, Baudner S, Bienvenu $\mathrm{J}$, et al. Consensus of a group of professional societies and diagnostic companies on guidelines for interim reference ranges for 14 proteins in serum based on standardization against the IFCC/BCR/CAP reference material (CRM 470). Eur J Clin Chem Clin Biochem 1996; 34:517-20.

27. Barrow GM. Equilibria in chemical and biological systems. In: Barrow GM, editor. Physical chemistry for the life sciences. 2nd ed. New York: McGraw-Hill, 1981:172-213.

28. Maes M, Cooreman W, Delanghe J, Scharpé S, Wauters A, Neels $\mathrm{H}$, et al. Components of biological variation in plasma haptoglobin: relationships to plasma fibrinogen and immune variables, including interleukin-6 and its receptor. Clin Chim Acta $1995 ; 239: 23-35$.

29. Macey MG. Immunophenotypic analysis of lymphocytes and leukemias. In: Macey MG, editor. Flow cytometry: clinical applications. Oxford: Blackwell Scientific Publications, 1994:67-100.

30. Shaw S. Leucocyte differentiation antigen database. In: Schlossmann SF, Boumsell L, Gilks W, Harlan JM, Kishimoto T, Morimoto C, Ritz J, Shaw S, Silverstein R, Springer T, Tedder TF, Todd RF, editors. Leucocyte typing V. Proceedings of the fifth International Workshop on Human Leucocyte Differentiation Antigens; 1993 Nov 3-7; Oxford: University Press, 1995:74.

31. McCormick DJ, Atassi MZ. Hemoglobin binding with haptoglobin: delineation of the haptoglobin binding site on the alpha-chain of human hemoglobin. J Prot Chem 1990; 9:735-42.

32. Barclay AN, Birkeland ML, Brown MH, Beyers AD, Davis SJ, Somoza C, Williams AF, editors. The leucocyte antigen FactsBook. London: Academic Press, 1993:148-9.

33. Law C-L, Sidorenko SP, Chandran KA, Zhao Z, Shen S-H, Fischer EH, et al. CD22 associates with protein tyrosine phosphatase $1 \mathrm{C}$, Syk, and phospholipase $\mathrm{C}-\gamma 1$ upon B cell activation. J Exp Med 1996; 183:547-60.

34. Stamenkovic I, Seed B. The B cell antigen CD22 mediates monocyte and erythrocyte adhesion. Nature 1990; 345:74-7.

35. Engel P, Nojima Y, Rothstein D, Zhou L-J, Wilson GL, Kehrl $\mathrm{JH}$, et al. The same epitope on CD22 of B lymphocytes mediates the adhesion of erythrocytes, $T$ and $B$ lymphocytes, neutrophils and monocytes. J Immunol 1993; 150:4719-32.

36. Law C-L, Sidorenko SP, Clark EA. Regulation of lymphocyte activation by the cell-surface molecule CD22. Immunol Today 1994; 15:442-9.

37. Clark EA, Ledbetter JA. How B and T cells talk to each other. Nature 1994; 367:425-8.

38. Turner GA. N-glycosylation of serum proteins in disease and its investigation using lectins. Clin Chim Acta 1992; 208:149-71.

39. Langlois M, Delanghe J, De Buyzere M. Relation between serum immunoglobulin A concentration and haptoglobin type. Clin Chem 1996; 42:1722-3.

\section{Received September 6/December 19, 1996}

Corresponding author: Prof. Dr. J. Delanghe, Central Laboratory 1B2, University Hospital Gent, De Pintelaan 185, B-9000 Gent, Belgium 
